2

5

\title{
Title: Characterization of Organic and Black Carbon Aerosol Formation during Coal Combustion: An Experimental Study in a 1 Megawatt Pilot Scale Coal Combustor
}

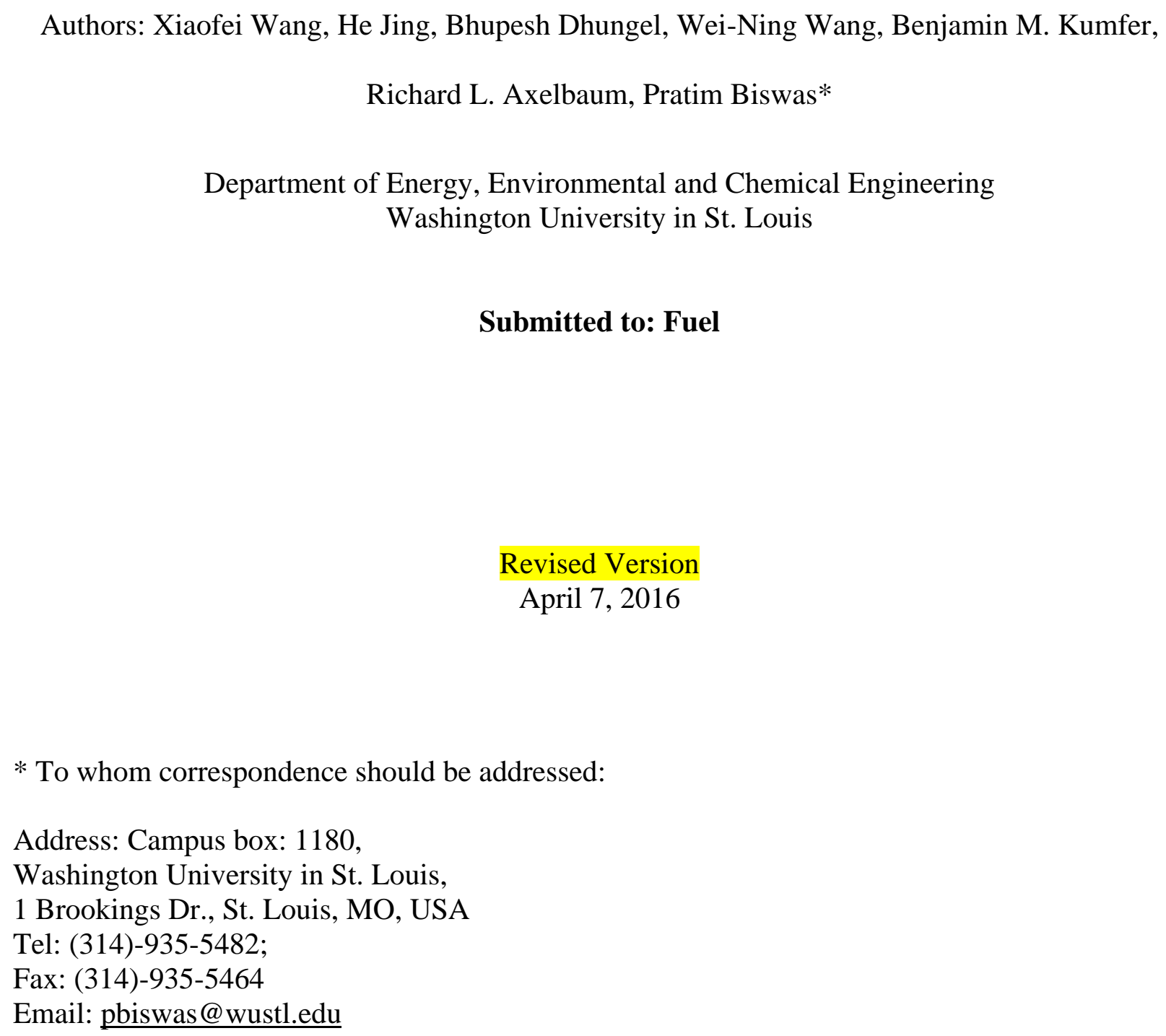




\section{Abstract}

2 Combustion is a main source of atmospheric aerosols, including organic carbon (OC) and black

3 carbon (BC). A pilot-scale coal combustor was used to investigate the formation of organic

4 carbon (OC) and black carbon (BC) aerosols under various combustion conditions. It was found

5 that $\mathrm{BC}$ aerosol formation was extremely sensitive to the fuel-oxidizer equivalence ratio: its

6 concentration decreased from $236 \mu \mathrm{g} / \mathrm{m}^{3}$ to $2.4 \mu \mathrm{g} / \mathrm{m}^{3}$, when the equivalence ratio was reduced

7 from 0.92 to 0.80 . However, the emissions of inorganic and $\mathrm{OC}$ aerosols were not sensitive to

8 the fuel-oxidizer equivalence ratio. The formation of OC aerosols seemed to be enhanced by

9 decreasing the fuel-oxidizer equivalence ratio, which was opposite to the change of $\mathrm{BC}$ aerosol

10 formation. Coal was also combusted in oxygen-rich environments. Inorganic submicrometer

11 particle formation was greatly enhanced in the oxygen-rich combustion mode, compared to

12 conventional air firing. Significant concentrations of OC aerosol were still present in the exhaust

13 gas, while concentrations of black carbon aerosol were under detection limit. The different

14 trends of $\mathrm{BC}$ and $\mathrm{OC}$ aerosol formation indicate that the formation pathways of OC aerosol are

15 very different from that of BC aerosol formation. 


\section{Introduction}

3 Atmospheric aerosols play a critical role in affecting radiative forcing and human health [1].

4 Carbonaceous aerosols, including elemental (black) and organic carbon aerosols, draw much

5 attention due to their unique properties of absorbing or scattering sun light and their potential

6 hazards for human health [2-4]. It is well established that black carbon (BC) aerosols can

7 absorb sunlight, thereby leading to positive radiative forcing. The recent Intergovernmental

8 Panel on Climate Change (IPCC) report suggested that radiative forcing of black carbon aerosols

9 was $+0.64 \mathrm{~W} / \mathrm{m}^{2}$, with uncertainty bounds of $(+0.25,+1.08) \mathrm{W} / \mathrm{m}^{2}$, during the year from 1750 to

102011 (IPCC 2013) [5]. Bond et al. provides an estimate that direct radiative forcing of black

11 carbon aerosols is $+0.71 \mathrm{~W} / \mathrm{m}^{2}$, with uncertainty bounds of $(+0.08,+1.27) \mathrm{W} / \mathrm{m}^{2}$ during the year

12 from 1750 to 2005, and suggests that black carbon could be the second most important

13 greenhouse agent from anthropogenic emissions [6]. Organic carbon (OC) aerosols comprise $20 \%$

14 to $80 \%$ of the total fine aerosol mass [2]. It is generally considered that organic aerosols affect

15 radiative forcing mainly by scattering sunlight. However, many recent studies indicate that some

16 organic aerosols, known as "brown organic aerosols" can also absorb sunlight [7, 8] and may

17 play an important role in climate change.

18 Coal combustion is a major type of fossil fuel combustion, used for electricity generation, 19 ranging from $39 \%$ in the United States, to over $70 \%$ in India and China $[9,10]$. It is reported

20 that carbonaceous aerosols are usually formed during coal combustion [11-21]. Many studies

21 have investigated formation of soot during coal combustion [18, 22-24]. Soot particles usually

22 contain a main fraction of black carbon and a very minor fraction of organic carbon. Veranth et

23 al. [25] studied unburned carbon in coal fly ash from a low-NOx pulverized coal burner and

24 found the carbon was bimodally distributed: carbonaceous aerosols with submicrometer sizes 
1 were from soot, while other carbonaceous aerosols with supermicrometer sizes (usually larger

2 than $10 \mu \mathrm{m}$ ) were from unburned char or soot aggregates. Brown and Fletcher proposed a model

3 to describe soot formation during coal combustion. They assumed that tar was the precursor of

4 soot. Under high temperature, tar was reported to directly lose $\mathrm{H}, \mathrm{O}$ and other atoms to form

5 soot. Brown and Fletcher built a model based on this assumption, and obtained good agreement

6 with the experiment [23]. Chen et al. investigated morphologies of carbonaceous aerosol from

7 coal combustion using electron microscopy; and found that the soot particles consisted of chains

8 of spherical nanoparticles, which contain several graphite layers [26].

9 There are few studies on formation of organic aerosols during coal combustion. In addition,

10 pilot-scale data is strongly needed on how formation of carbonaceous aerosol changes with

11 operating conditions of the combustor. This work reports a systematic study on the formation of

12 aerosols, including $\mathrm{BC}$ and $\mathrm{OC}$ aerosols, in a 1 Megawatt pilot scale coal combustor under

13 various combustion conditions.

\section{Experimental Section}

$15 \quad 2.1$ Experimental Setup of Pulverized Coal Combustion in a $1 \mathrm{MW}$ pilot-scale coal combustor

16 The 1 MW pilot-scale coal combustor with a boiler is located in the Advanced Coal and Energy

17 Research Facility (ACERF, Website: http://cccu.wustl.edu) at Washington University in St.

18 Louis. Figure 1 shows the schematic drawing of the coal combustion system. A detailed

19 description of ACERF can be found in the supporting information (Fig.S1-S3). West Elk coal (a

20 low-sulfur, Colorado bituminous coal) was used in the tests. The flue gas composition was

21 monitored by a Horiba portable gas analyzer (Model PG-250). After the boiler, a slip stream (13

22 liter per min, LPM) of the exhaust gas was drawn to conduct the particle measurements. 5 LPM 
1 of exhaust gas was sent to an Aerodynamic particle sizer (APS, TSI Inc.). Another 8 LPM of

2 exhaust gas passed through an impactor which was used to remove supermicrometer particles.

3 Then this gas stream was dried by a diffusional dryer and connected to a scanning mobility

4 particle sizer (SMPS, TSI Inc.) and a filter holder, which was used to collect the particles from

5 flue gas. Four or more size distribution measurements were done for each test. Both Telfon

6 filter and quartz filter were used to collect the particles. The collected particles were analysed

7 for elemental and organic carbon (EC/OC) concentrations using a thermal/optical carbon

8 analyzer (Model 2001, Atmoslytic Inc., Calabasas, CA) [27]; and X-ray fluorescence (XRF)

9 analysis with a Panalytical Epsilon 5 energy dispersive XRF spectrometer for determining

10 elemental compositions of the collected particles. Noticeably, it was unlikely that a significant

11 amount of sulfuric acid was condensed in the sampling system, since the temperature $\left(\sim 110^{\circ} \mathrm{C}\right)$

12 of outlet of the boiler was lower than acid dew point $\left(\sim 120^{\circ} \mathrm{C}\right)$. Most acid gas may condense

13 before exiting the boiler. To prevent water condensation in the sampling system, the sampled

14 flue gas was heated to about $100{ }^{\circ} \mathrm{C}$ till it reached the diffusional dryer.

\section{$15 \quad 2.2$ Test plan}

16 The test plan is summarized in Table 1. Experimental set 1 was operated under conventional air-

17 firing mode. The equivalence ratio was varied by changing the input air flow rate. The three

18 tests in the experimental set 1 had evenly spaced fuel-oxidizer equivalence ratios of $0.92,0.80$

19 and 0.72 , respectively. Their excess oxygen were $9 \%, 25 \%$ and 39\%, respectively. Coal fired

20 utility boilers usually operate using between 20 and $40 \%$ excess air. Thus, two conditions (20\%,

21 Test 2 and 28\%, Test 3) were in this range. An additional condition (9\% excess air, Test 1) was

22 also chosen to be below this range to investigate how this affected aerosol formation, especially 
1 for the formation of $\mathrm{BC} / \mathrm{OC}$ aerosols. Experimental set 2 was operated under oxygen-rich

2 conditions, with pure oxygen being added to the input air stream.

3 The fuel-oxidizer equivalence ratio $(\phi)$ was calculated based on the following equation:

$$
\phi=\frac{m_{\text {fuel }} / m_{\text {oxidizer }}}{\left(m_{\text {fuel }} / m_{\text {oxidizer }}\right)_{s t}}
$$

4 where $\mathrm{m}$ is the mass and suffix "st" stands for stoichiometric conditions.

5

\section{$6 \quad 3$ Results and Discussion}

73.1 Characterization of Organic Carbon (OC) Aerosol and Black Carbon (BC) Aerosol from 8 Conventional Air Firing of Coal

9 As described in Table 1, Experimental Set \#1 includes three tests performed at different fuel10 oxidizer equivalence ratios. Particle size distributions were measured. Figure 2 shows the size 11 distributions of particles measured by the SMPS and APS instruments. The particle size 12 distribution did not change significantly when changing the fuel-oxidizer equivalence ratio.

13 The smaller particles have a slightly higher sensitivity to the fuel-oxidizer ratios. Figure 2 shows 14 that decreasing the fuel-oxidizer equivalence ratio led to a slight increase in the number 15 concentration for particles smaller than $100 \mathrm{~nm}$. Moreover, the particle concentration for Test 1 16 (fuel-oxidizer equivalence ratio $=0.92$ ) in the size range from 100 to $400 \mathrm{~nm}$ is significantly 17 higher than for the other two conditions. EC/OC (elemental carbon/organic carbon) analysis has 18 been conducted for the aerosol samples shown in Fig. 3. It is usually considered that EC 19 (elemental carbon) is similar to BC (black carbon) [1], even though EC and BC are actually 
1 defined by two different analysis methods: EC is a measure of carbon from a certain thermal

2 procedure, while $\mathrm{BC}$ is based on a measure of light absorbance. In this study, EC is assumed to

3 be equal to $\mathrm{BC}$. Figure 4 shows the concentrations of $\mathrm{BC}$ and $\mathrm{OC}$ aerosol in the flue gas. The

4 equivalence ratio for Test 1 was 0.92 , higher than the normal operating condition of a typical

5 pulverized coal boiler, which ranges from 0.71 to 0.83 (corresponding to 40 to $20 \%$ excess

6 oxygen) [28]. The measured $\mathrm{CO}$ concentration in the exhaust gas was low (about $55 \mathrm{ppm}$ )

7 (Table 2), indicating complete combustion conditions. (In most states in the US, the upper

8 allowed limit for CO concentration in the exhaust gas is from about 40 to $60 \mathrm{ppmv}$.) However,

9 soot emission was significantly greater in Test 1 . The BC aerosol concentration in flue gas was

10 found to be $236 \mu \mathrm{g} / \mathrm{m}^{3}$, which accounts for $29 \%$ of the total fine particulate mass (particle size $\leq$

$11500 \mathrm{~nm}$ ). When the equivalence ratio decreased to 0.80 (the $\mathrm{O}_{2}$ concentration in the flue gas was

$124 \%$ in this case), the BC aerosol concentration dropped drastically to $2.4 \mu \mathrm{g} / \mathrm{m}^{3}$, which was about

13 only $1 \%$ of the $\mathrm{BC}$ concentration from Test 1 . If the equivalence ratio was further decreased to

14 0.72, then no $\mathrm{BC}$ aerosol concentration could be detected. These results suggest that the

15 emission of $\mathrm{BC}$ aerosols is extremely sensitive to changes in the fuel-oxidizer equivalence ratio.

16 Interestingly, the particle concentrations for Test 1 in the size range from 100 to $400 \mathrm{~nm}$ (Fig. 2)

17 was significantly higher and had much larger variations than the other two conditions (Test 2 and

18 3), suggesting these particles were formed via a distinct pathway from normal inorganic fly ash

19 particle formation. This pathway was probably associated with the formation of black carbon

20 aerosol (soot).

21 Organic carbon aerosol concentration was not as sensitive as $\mathrm{BC}$ aerosol emission to the fuel-

22 oxidizer equivalence ratio. Figure 4 shows that $\mathrm{OC}$ aerosol emission was actually enhanced at a

23 lower fuel-oxidizer equivalence ratio. This phenomenon strongly indicates that the formation 
1 pathway of $\mathrm{OC}$ aerosol was very different from $\mathrm{BC}$ aerosol formation. Our previous work

2 observed a correlation between inorganic particle concentration and organic aerosol formation,

3 and it proposed that inorganic particles play a critical role as carriers of organic aerosols [19]:

4 inorganic fly ash particles may adsorb organic species from the gas phase to their surfaces. And

5 they may also protect these organics from complete oxidation under the high temperature

6 environment Figure 2 does show that the particle size distributions below $100 \mathrm{~nm}$ shifted to

7 larger sizes when the fuel-oxidizer equivalence ratio was lowered. Thus, the changes of OC

8 aerosol concentrations in this case may be associated with the changes of inorganic particle

9 concentrations in the flue gas.

10 Particle size distribution in coal combustion flue gas was also obtained using a Nano differential

11 mobility analyzer (Nano DMA), which is able to measure extremely fine particles. Figure S4

12 shows that the concentrations of particles with sizes smaller than $10 \mathrm{~nm}$ were very low. One

13 possibility is that coal flue gas contains a high concentration of particles and other condensable

14 gases, such as $\mathrm{SO}_{3}$ and $\mathrm{H}_{2} \mathrm{O}$. Thus, ultrafine particles in this range will quickly grow to larger

15 particles.

3.2 Characterization of Organic Aerosol and Black Carbon Aerosol during Oxygen-rich

\section{Combustion}

In this study, an oxygen-rich combustion mode was also tested. Pure oxygen was mixed with air

19 to increase the oxygen concentration in the input gas. Test 4 was performed under $39 \%$ (v/v) oxygen; and Test 5 was performed under $49 \%$ (v/v) oxygen. It is well known that increasing

21 oxygen concentration can significantly enhance submicrometer inorganic particle formation, due

22 to enhancement of the vaporization-nucleation pathway [29-34]. Metal oxides in coal are 
1 reduced to metals or metal suboxides while coal particles are burning. These metals or metal

2 suboxides usually have higher volatility; and some of them may be converted into vapors. The

3 vapors can be quickly oxidized back to metal oxides by oxygen when they diffuse away from the

4 coal particle surface. Then gas-to-particle conversion, including nucleation, condensation and

5 coagulation, occurs to form submicrometer particles. Increasing oxygen concentration can

6 increase the surface temperature of coal particles, thereby enhancing the evaporation of metal

7 oxides. Then higher submicrometer particulate mass is formed. In this study, Figure 5 confirms

8 this theory: the increasing of oxygen concentration resulted in a significant shift in particle size

9 distribution to larger sizes for submicrometer particles. Figure 6 shows the concentration of

10 selected elements of these submicrometer particles in the flue gas.. The concentrations of most

11 elements increase greatly with higher oxygen concentrations. It should be noted that the air

12 firing case (Test 3) was performed at a higher coal feed rate $(400 \mathrm{KW})$, while the oxygen-rich

13 combustion cases (Test 4 and 5) were performed at a lower coal feed rate $(270 \mathrm{KW})$. Increasing

14 firing rate results in a larger flame, higher gas volume flow rate and, therefore, reduced residence

15 time. However, according to our previous drop-tube study [19], the change of firing rate did not

16 greatly change the size distribution of submicron fly ash particles. Especially the peak of the

17 size distributions did not change significantly.

18 Figure 7 compares the BC/OC aerosol concentration for two oxygen-rich combustion cases and 1

19 air-firing case. The $\mathrm{BC}$ aerosol concentrations are 0 for all three cases, since the fuel-oxidizer

20 equivalence ratio was low, especially for oxygen-rich combustion cases. But surprisingly, there

21 were still significant OC aerosol concentrations from oxygen-rich combustion flue gas. And

22 more surprisingly, the OC concentration was even higher in Test $5\left(49 \% \mathrm{O}_{2}\right.$ case $)$ than that in

23 Test $4\left(39 \% \mathrm{O}_{2}\right.$ case $)$, suggesting that the fuel-oxidizer equivalence ratio may not be a dominant 
1 factor affecting OC aerosol formation. Other factors, such as inorganic particle concentration,

2 may play a critical role in OC aerosol formation: under oxygen-rich conditions, the flame

3 temperature tended to be higher than conventional air firing. It would result in formation of

4 more submicrometer sized inorganic ash particles. According to our previous studies [19], OC

5 aerosol formation could be enhanced in the presence of higher concentration of submicron

6 inorganic ash particles.

\section{$7 \quad 3.3$ Environmental Implications of This Study}

8 This study reports distinct differences in BC and OC aerosol formation during coal combustion.

9 It is found that a slight change of fuel-oxidizer ratio could result in a significant change of $\mathrm{BC}$

10 aerosol formation. However, to access the global BC aerosol emission from coal-fired power

11 plants and its impact on climate, a single emission factor (mass of BC aerosol emitted per unit

12 mass of coal burned) has been used [6]. This emission factor is multiplied by the coal usage, and

13 the product is the calculated $\mathrm{BC}$ aerosol emission (Tg per year) from coal-fired power plants.

14 This method does not account for variation of emission factor of $\mathrm{BC}$ aerosol emissions, which

15 could be quite large, as shown in this study. Considering the measurement of emission factor

16 was usually done in developed countries, such as United States [17], applying this emission

17 factor to developing countries, where operation of coal-fired power plant may be less regulated,

18 is probably problematic. Therefore, the emission from coal-fired power plants in developing

19 countries cannot be estimated by extrapolating from US coal-fired power plants.

20 This study also shows that OC aerosol formation from coal combustion is not sensitive as BC

21 aerosol emission. Thus, the previous estimate of OC aerosol emission from coal-fired power

22 plants [17], which also use single emission factor, should be more reliable than that of BC 23 aerosol emission. 
2 Pilot-scale experiments were conducted in a $1 \mathrm{MW}$ coal combustor. It is shown that black 3 carbon aerosol formation was extremely sensitive to the fuel-oxidizer equivalence ratio. The

4 elemental (black) carbon aerosol concentration in flue gas decreased from $236 \mu \mathrm{g} / \mathrm{m}^{3}$ to only 2.4

$5 \mu \mathrm{g} / \mathrm{m}^{3}$ when the fuel-oxidizer equivalence ratio was reduced from 0.92 to 0.80 . (The $\mathrm{O}_{2}$

6 concentration in flue gas was changed from $1.7 \%$ to $4.16 \%)$. The emission of organic carbon

7 aerosol was not as sensitive as black carbon aerosol. And the results suggested that organic

8 carbon aerosol formation was enhanced by increasing the fuel-oxidizer equivalence ratio, which

9 was opposite to the change of black carbon aerosol formation. This phenomenon indicates that

10 the formation mechanism of organic carbon aerosol should be very different from that of black

11 carbon aerosol.

12 The coal combustor was also operated in oxygen-rich combustion mode. Pure oxygen was 13 mixed with air to increase oxygen concentration in the input gas. Inorganic submicrometer 14 particle formation was greatly enhanced in the oxygen-rich combustion mode, compared to 15 conventional air firing (peak size was shifted from $53 \mathrm{~nm}$ (air-firing, Test 3) to $143 \mathrm{~nm}$ (oxygen16 rich, Test 5)). Black carbon aerosol concentration was under the detection limit. However, 17 surprisingly, there was still a significant concentration of organic carbon aerosol present in the 18 flue gas, although the fuel-oxidizer equivalence ratio was very low in this mode, which may 19 indicate that the fuel-oxidizer equivalence ratio is not a dominate factor affecting organic carbon 20 aerosol formation. 


\section{Acknowledgments}

2 This work was partially supported by a grant from National Science Foundation (NSF 3 CBET 1437933) and the Consortium for Clean Coal Utilization at Washington University in St.

4 Louis. Support of the McDonnell Academy Global Energy and Environment Partnership 5 (MAGEEP) is also acknowledged. 
3 1. U. Poschl, Atmospheric aerosols: Composition, transformation, climate and health effects, 4 Angew. Chem. Int. Ed. Engl. 2005; 44:7520-7540.

5 2. M. Hallquist, J. C. Wenger, U. Baltensperger, Y. Rudich, D. Simpson, M. Claeys, J.

6 Dommen, N. M. Donahue, C. George, A. H. Goldstein, J. F. Hamilton, H. Herrmann, T.

7 Hoffmann, Y. Iinuma, M. Jang, M. E. Jenkin, J. L. Jimenez, A. Kiendler-Scharr, W. Maenhaut,

8 G. McFiggans, T. F. Mentel, A. Monod, A. S. H. Prevot, J. H. Seinfeld, J. D. Surratt, R.

9 Szmigielski, J. Wildt, The formation, properties and impact of secondary organic aerosol: current 10 and emerging issues, Atmos. Chem. Phys. 2009; 9:5155-5236.

11 3. M. Kanakidou, J. H. Seinfeld, S. N. Pandis, I. Barnes, F. J. Dentener, M. C. Facchini, R.

12 Van Dingenen, B. Ervens, A. Nenes, C. J. Nielsen, E. Swietlicki, J. P. Putaud, Y. Balkanski, S.

13 Fuzzi, J. Horth, G. K. Moortgat, R. Winterhalter, C. E. L. Myhre, K. Tsigaridis, E. Vignati, E. G.

14 Stephanou, J. Wilson, Organic aerosol and global climate modelling: a review, Atmos. Chem.

15 Phys. 2005; 5:1053-1123.

16

$17 \quad$ Nature Geosci. 2008; 1:221-227.

18 5. IPCC, 2013: Climate Change 2013: The Physical Science Basis. Contribution of Working 19 Group I to the Fifth Assessment Report of the Intergovernmental Panel on Climate

20 Change [Stocker, T.F., D. Qin, G.-K. Plattner, M. Tignor, S.K. Allen, J. Boschung, A. Nauels, Y.

21 Xia, V. Bex and P.M. Midgley (eds.)]. Cambridge University Press, Cambridge, United

22 Kingdom and New York, NY, USA. 
1 6. T. C. Bond, S. J. Doherty, D. W. Fahey, P. M. Forster, T. Berntsen, B. J. DeAngelo, M. G.

2 Flanner, S. Ghan, B. Kärcher, D. Koch, S. Kinne, Y. Kondo, P. K. Quinn, M. C. Sarofim, M. G.

3 Schultz, M. Schulz, C. Venkataraman, H. Zhang, S. Zhang, N. Bellouin, S. K. Guttikunda, P. K.

4 Hopke, M. Z. Jacobson, J. W. Kaiser, Z. Klimont, U. Lohmann, J. P. Schwarz, D. Shindell, T.

5 Storelvmo, S. G. Warren, C. S. Zender, Bounding the role of black carbon in the climate system:

6 A scientific assessment, Journal of Geophysical Research: Atmospheres 2013; 118:5380-5552.

7 7. M. O. Andreae, A. Gelencsér, Black carbon or brown carbon? The nature of light-

8 absorbing carbonaceous aerosols, Atmos. Chem. Phys. 2006; 6:3131-3148.

9 8. Ö. Gustafsson, M. Kruså, Z. Zencak, R. J. Sheesley, L. Granat, E. Engström, P. S.

10 Praveen, P. S. P. Rao, C. Leck, H. Rodhe, Brown Clouds over South Asia: Biomass or Fossil

11 Fuel Combustion?, Science 2009; 323:495-498.

12 9. P. Biswas, W. N. Wang, W. J. An, The energy-environment nexus: aerosol science and

13 technology enabling solutions, Front. Environ. Sci. Eng. China 2011; 5:299-312.

14 10. U.S. Energy Information Admistration, Electric Power Monthly. In 2014.

15 11. X. Wang, E. Cotter, K. N. Iyer, J. Fang, B. J. Williams, P. Biswas, Relationship between

16 pyrolysis products and organic aerosols formed during coal combustion, Proc. Combust. Inst.

$17 \quad 2015 ; 35: 2347-2354$.

18 12. I. Olmez, A. E. Sheffield, G. E. Gordon, J. E. Houck, L. C. Pritchett, J. A. Cooper, T. G.

19 Dzubay, R. L. Bennett, Compositions of Particles from Selected Sources in Philadelphia for

20 Receptor Modeling Applications, Japca-the International Journal of Air Pollution Control and

21 Hazardous Waste Management 1988; 38:1392-1402. 
1 13. G. L. Fisher, B. A. Prentice, D. Silberman, J. M. Ondov, A. H. Biermann, R. C. Ragaini,

2 A. R. McFarland, Physical and morphological studies of size-classified coal fly ash, Environ. Sci.

3 Technol. 1978; 12:447-451.

4 14. Y. Mamane, J. L. Miller, T. G. Dzubay, Characterization of individual fly ash particles

5 emitted from coal- and oil-fired power plants, Atmos. Environ. 1986; 20:2125-2135.

6 15. X. Querol, R. Juan, A. Lopez-Soler, J. Fernandez-Turiel, C. R. Ruiz, Mobility of trace

7 elements from coal and combustion wastes, Fuel 1996; 75:821-838.

8 16. R. D. Smith, J. A. Campbell, K. K. Nielson, Characterization and formation of submicron 9 particles in coal-fired plants, Atmos. Environ. 1979; 13:607-617.

10 17. T. C. Bond, D. G. Streets, K. F. Yarber, S. M. Nelson, J.-H. Woo, Z. Klimont, A

11 technology-based global inventory of black and organic carbon emissions from combustion, J.

12 Geophys. Res. 2004; 109:D14203.

13 18. W. P. Linak, J.-I. K. Yoo, S. J. Wasson, W. Zhu, J. O. L. Wendt, F. E. Huggins, Y. Chen,

14 N. Shah, G. P. Huffman, M. I. Gilmour, Ultrafine ash aerosols from coal combustion:

15 Characterization and health effects, Proc. Combust. Inst. 2007; 31:1929-1937.

16 19. X. Wang, B. J. Williams, Y. Tang, Y. Huang, L. Kong, X. Yang, P. Biswas,

17 Characterization of organic aerosol produced during pulverized coal combustion in a drop tube 18 furnace, Atmos. Chem. Phys. 2013; 13:10919-10932.

19 20. A. M. Mastral, M. S. Callén, T. Garcia, Toxic organic emissions from coal combustion, 20 Fuel Process. Technol. 2000; 67:1-10. 
1 21. A. M. Mastral, M. S. Callén, A Review on Polycyclic Aromatic Hydrocarbon (PAH)

2 Emissions from Energy Generation, Environ. Sci. Technol. 2000; 34:3051-3057.

3 22. W. J. Morris, D. Yu, J. O. L. Wendt, Soot, unburned carbon and ultrafine particle

4 emissions from air- and oxy-coal flames, Proc. Combust. Inst. 2011; 33:3415-3421.

5 23. A. L. Brown, T. H. Fletcher, Modeling Soot Derived from Pulverized Coal, Energy Fuels $6 \quad 1998 ; 12: 745-757$.

7 24. Z. A. Mansurov, Soot formation in combustion processes (review), Combustion

8 Explosion and Shock Waves 2005; 41:727-744.

9 25. J. M. Veranth, T. H. Fletcher, D. W. Pershing, A. F. Sarofim, Measurement of soot and 10 char in pulverized coal fly ash, Fuel 2000; 79:1067-1075.

11 26. Y. Chen, N. Shah, A. Braun, F. E. Huggins, G. P. Huffman, Electron Microscopy

12 Investigation of Carbonaceous Particulate Matter Generated by Combustion of Fossil Fuels, 13 Energy Fuels 2005; 19:1644-1651.

14 27. J. C. Chow, J. G. Watson, L. C. Pritchett, W. R. Pierson, C. A. Frazier, R. G. Purcell, The 15 DRI thermal/optical reflectance carbon analysis system: description, evaluation and applications 16 in U.S. air quality studies, Atmos. Environ 1993; 27A (8), 1185-1201.

17 28. Babcock \& Wilcox Company, Steam: Its Generation and Use, Nabu Press, New York, 182010. 
1 29. X. Wang, S. Michael Daukoru, S. Torkamani, W.-N. Wang, P. Biswas, Role of exhaust

2 gas recycle on submicrometer particle formation during oxy-coal combustion, Proc. Combust.

$3 \quad$ Inst. 2013; 34:3479-3487.

$4 \quad 30 . \quad$ A. Suriyawong, M. Gamble, M.-H. Lee, R. Axelbaum, P. Biswas, Submicrometer

5 Particle Formation and Mercury Speciation Under O2-CO2 Coal Combustion, Energy Fuels

$6 \quad 2006 ; 20: 2357-2363$.

7 31. Y. Zhuang, P. Biswas, Submicrometer Particle Formation and Control in a Bench-Scale

8 Pulverized Coal Combustor, Energy Fuels 2001; 15:510-516.

9 32. A. F. Sarofim, J. B. Howard, A. S. Padia, The Physical Transformation of the Mineral

10 Matter in Pulverized Coal Under Simulated Combustion Conditions, Combust. Sci. Technol.

$11 \quad 1977 ; 16: 187-204$.

12 33. R. J. Quann, M. Neville, M. Janghorbani, C. A. Mims, A. F. Sarofim, Mineral Matter and

13 Trace-element Vaporization in a Laboratory-pulverized Coal Combustion System, Environ. Sci.

14 Technol. 1982; 16:776-781.

15 34. B. S. Haynes, M. Neville, R. J. Quann, A. F. Sarofim, Factors Governing the Surface

16 Enrichment of Fly-ash in Volatile Trace Species, Journal of Colloid and Interface Science 1982;

$17 \quad 87: 266-278$. 
1 Table 1. Test plan of experimental conditions in ACERF system

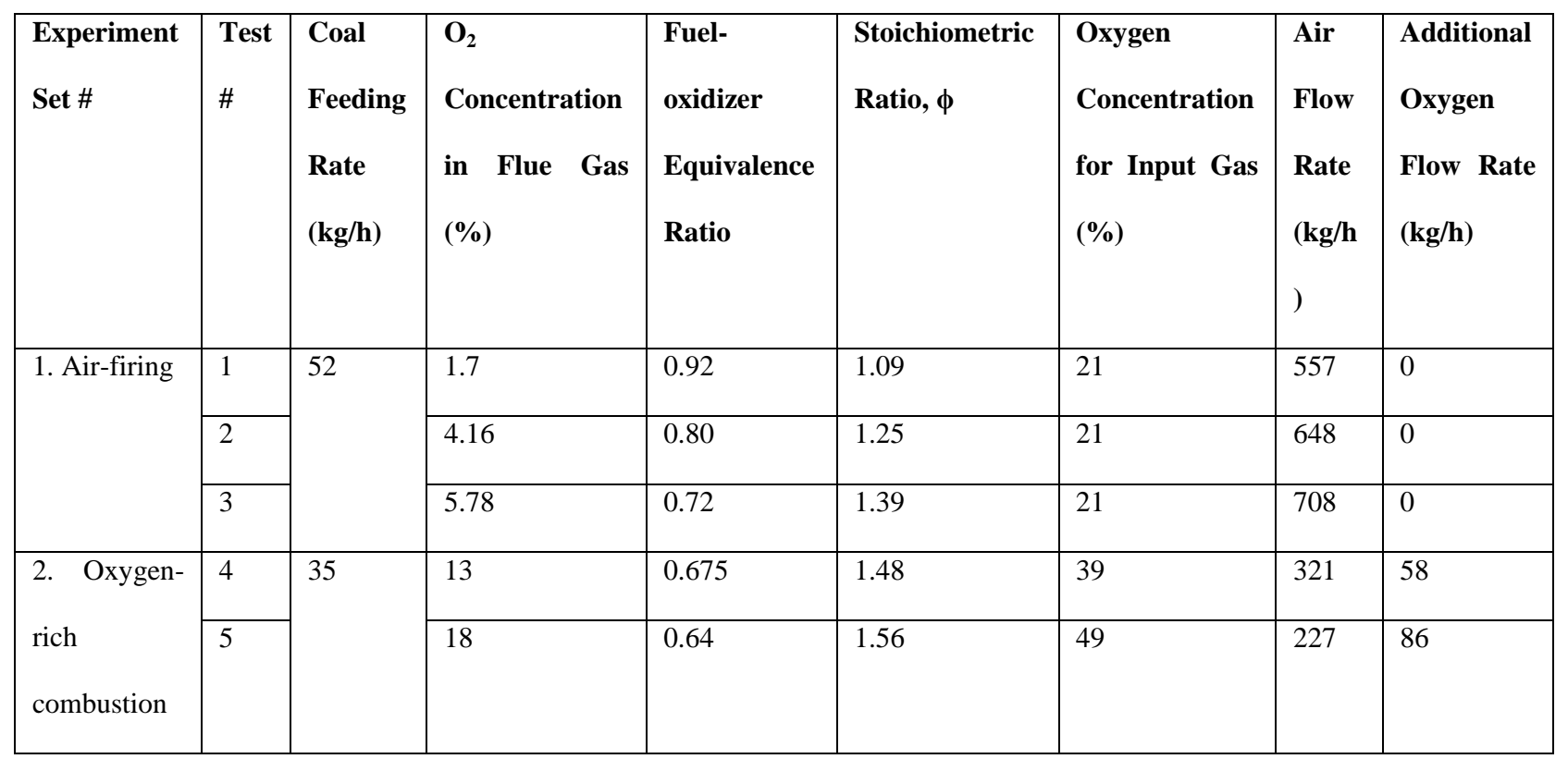


1 Table 2. Exhaust gas composition for each experimental condition

\begin{tabular}{|c|c|c|c|c|c|c|}
\hline Experiment Set \# & $\begin{array}{l}\text { Test } \\
\#\end{array}$ & $\begin{array}{l}\mathrm{O}_{2} \\
(\text { Vol. \%) }\end{array}$ & $\begin{array}{l}\mathrm{CO}_{2} \\
(\mathrm{Vol} . \%)\end{array}$ & $\begin{array}{l}\text { CO (Vol. } \\
\text { PPM })\end{array}$ & $\begin{array}{l}\text { NO (Vol. } \\
\text { PPM) }\end{array}$ & $\begin{array}{l}\text { Total Particle } \\
\text { Concentration* } \\
\left(\# / \mathrm{cm}^{3}\right)\end{array}$ \\
\hline \multirow[t]{3}{*}{ 1. Air-firing } & 1 & 1.7 & 17.29 & 55 & 382 & $3.4 \times 10^{6}$ \\
\hline & 2 & 4.16 & 14.42 & 9 & 685 & $4.1 \times 10^{6}$ \\
\hline & 3 & 5.78 & 14.86 & 13 & 712 & $5.0 \times 10^{6}$ \\
\hline \multirow{2}{*}{$\begin{array}{l}\text { 2. Oxygen-rich } \\
\text { combustion }\end{array}$} & 4 & 13 & 14.24 & 126 & 667 & $6.9 \times 10^{6}$ \\
\hline & 5 & 18 & 17 & 86 & 729 & $7.6 \times 10^{6}$ \\
\hline
\end{tabular}

$2 *$ The total particle concentrations were calculated from the particle size distributions from the

3 SMPS measurements 
1

2

3 Figure 1. Schematic drawing of the ACERF system

4 Figure 2. Size distributions of particles in coal combustion exhaust gas for Experimental Set \#1

5 (Four or more measurements had been done for each test. The error bars shows the standard

6 deviations).

7 Figure 3. Pictures of aerosol samples collected on filters during the combustion for Experimental

8 Set \#1 (Top: Telfon filter; Bottom: Quartz filter).

9 Figure 4. BC and OC emissions under different fuel-oxidizer equivalence ratios for Experimental

10 Set \#1 (the error bars show the uncertainty for the BC/OC measurement method). The OC/BC

11 ratios for Test 1,2 and 3 are 4.1, 0.047, and $\sim 0$

12 Figure 5. Size distributions of particles in coal combustion flue gas for oxygen enriched coal

13 combustion (Experiment Set \#2; the size distribution for Test 3 was normalized based on coal

14 feed rate)

15 Figure 6. Elemental compositions of submicrometer particles in coal combustion flue gas for

16 Experimental Set \#2

17 Figure 7. BC/OC aerosol concentrations under oxygen enriched coal combustion (Experiment

18 Set \#2) (the error bars show the uncertainty for the BC/OC measurement method) 


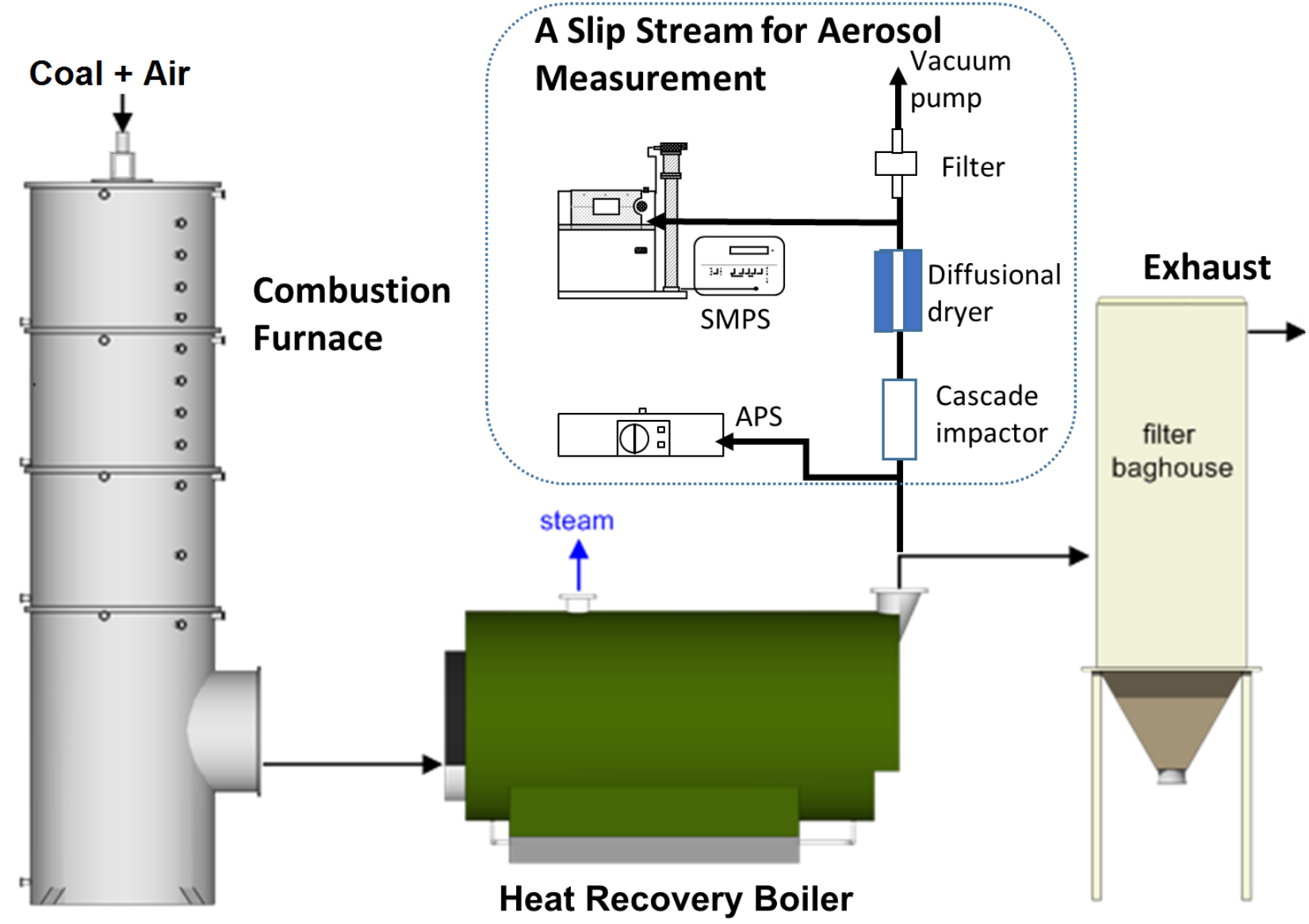

3 Figure 1. Schematic drawing of ACERF system 


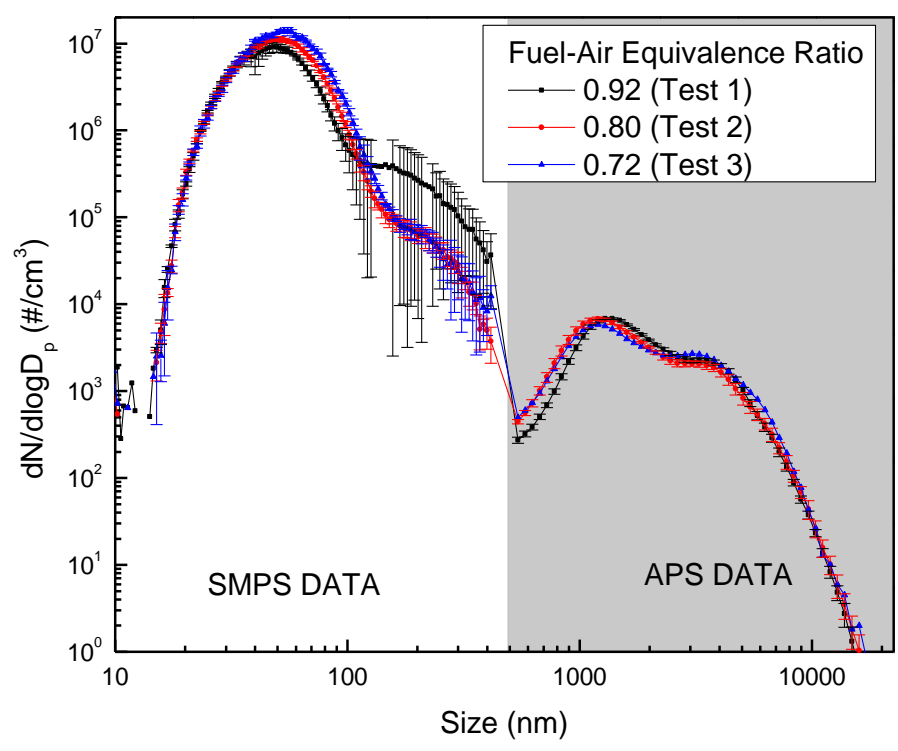

1

2 Figure 2. Size distributions of particles in coal combustion exhaust gas for Experimental Set \#1

3 (Four or more measurements had been done for each test. The error bars shows the standard

4 deviations). 


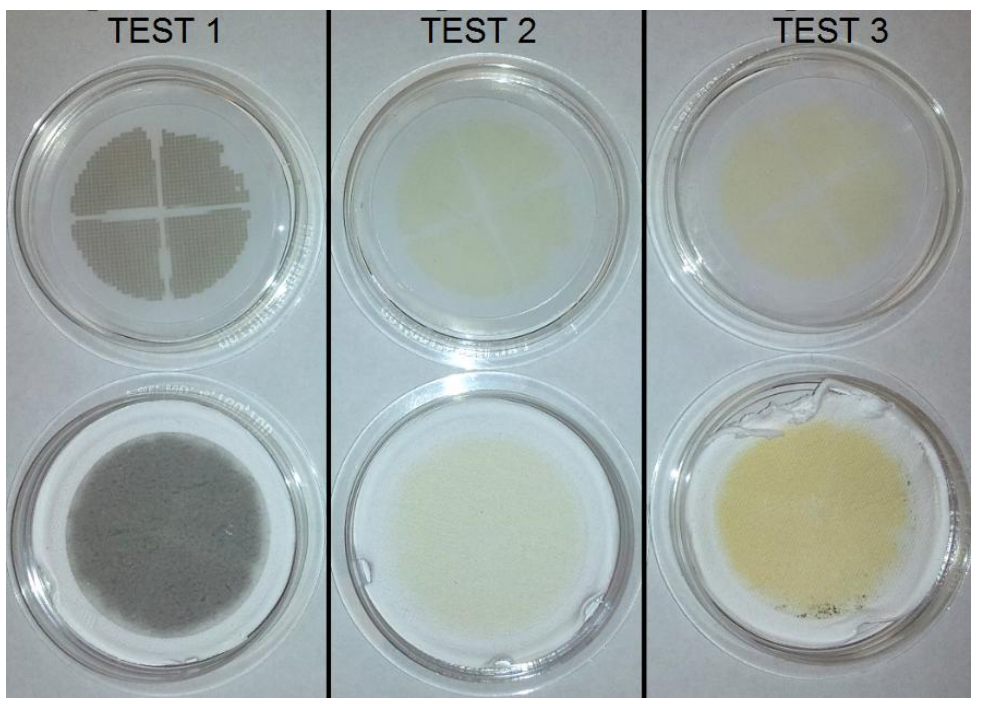

2 Figure 3. Pictures of aerosol samples collected on filters during the combustion for Experimental 3 Set \#1 (Top: Telfon filter; Bottom: Quartz filter).

4 


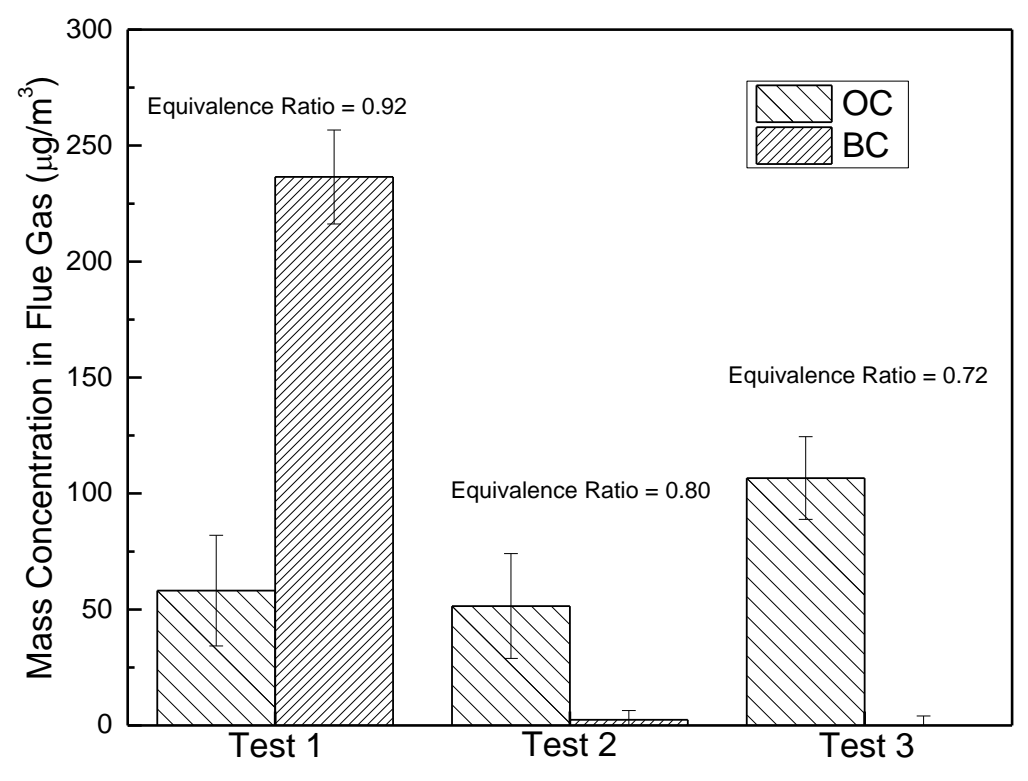

2 Figure 4. BC and OC emissions under different fuel-oxidizer equivalence ratios for Experimental

3 Set \#1 (the error bars show the uncertainty for the BC/OC measurement method). The OC/BC

4 ratios for Test 1, 2 and 3 are 4.1, 0.047, and $\sim 0$ 


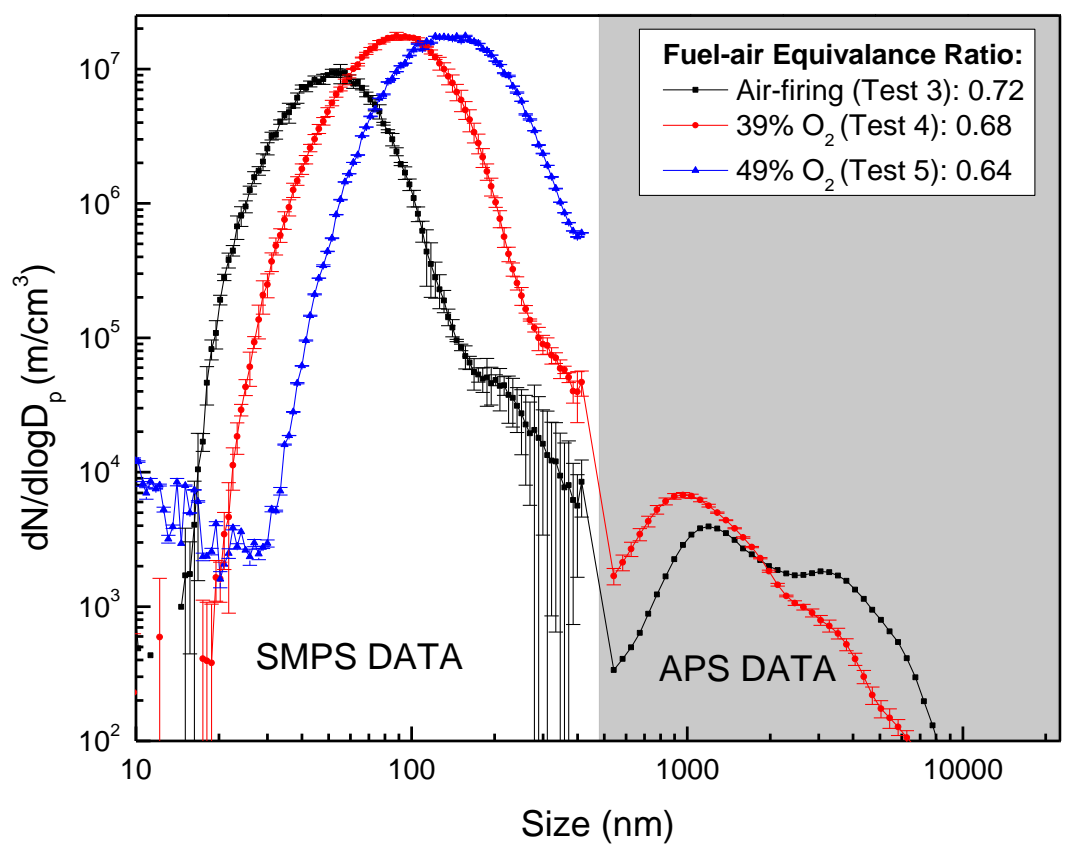

3 Figure 5. Size distributions of particles in coal combustion flue gas for oxygen enriched coal

4 combustion (Experimental Set \#2; the size distribution for Test 3 was normalized based on coal 5 feed rate) 


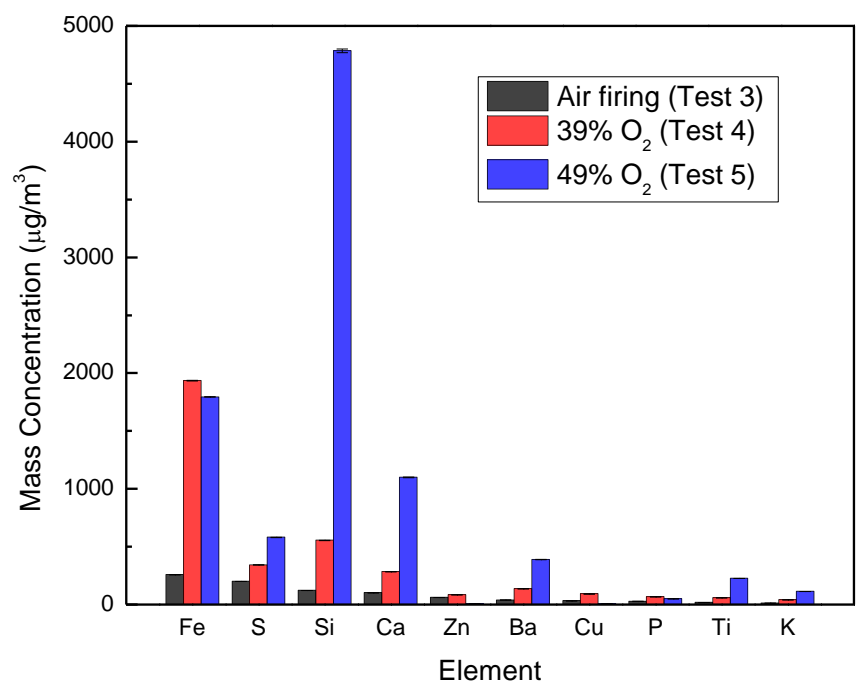

2

3 Figure 6. Elemental compositions of submicrometer particles in coal combustion flue gas for

4 Experimental Set \#2 


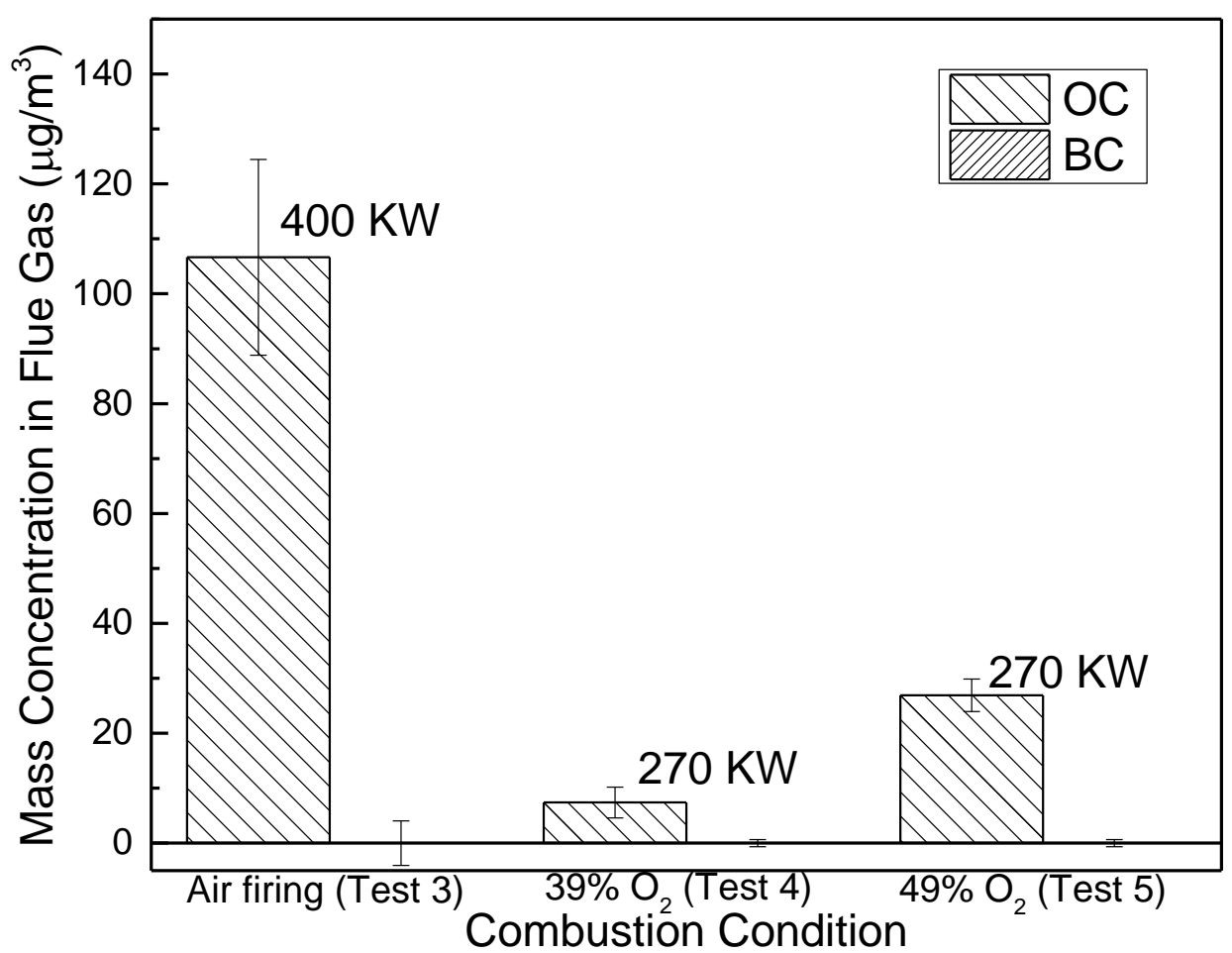

1

2 Figure 7. BC/OC aerosol concentrations under oxygen enriched coal combustion (Experimental

3 Set \#2) (the error bars show the uncertainty for the BC/OC measurement method)

4

5

6 